\title{
Physical habitat as predictor of fish trophic structure in Brazilian Atlantic a rainforest streams
}

Correspondence:

Alexandre Peressin alexandre.peressin@gmail.com

Submitted July 22, 2019

Accepted March 30, 2020

by Lilian Casatti

Epub Jun 17, 2020

Online version ISSN 1982-0224

Print version ISSN 1679-6225

Neotrop. Ichthyol.

vol. 18, no. 2, Maringá 2020

\section{${ }^{-}$Alexandre Peressin ${ }^{1,2},{ }^{\circ}$ Ruanny Casarim ${ }^{2},{ }^{\circ}$ Ivo Gavião Prado ${ }^{2,3}$ and ${ }^{-}$Mauricio Cetra ${ }^{4}$}

Trophic structure of fish assemblages is one of the most sensitive indicators of changes in streams environments. Since it is crucial to understand the response of trophic groups to habitat alteration, our study aimed to address this research gap by assessing the influence of substrate composition, meso-habitat variability, and bank stability, on the richness, biomass, and number of individuals of carnivores, invertivores, omnivores, and herbivorous-detritivores. Using an electrofishing device, we sampled 13 Atlantic rainforest streams reaches in a degradation gradient, located in the upper Paranapanema river basin. Sample points were ranked using a physical habitat index. More pristine streams had high availability of twigs, trunks, rocks and boulders in the substrate, great meso-habitat variability, and the presence of roots, trunks, and rocks in the margins. Canonical correlations between habitat characteristics and trophic groups explained more than $90 \%$ of data variability. Richness and number of individuals of invertivores increased in more preserved stream reaches, while richness of carnivores and number of individuals of omnivores decreased. These results demonstrate that trophic structure varies according to level of degradation, and that invertivore richness represents the best indicator of fish trophic structure responses to physical habitat alterations in streams.

Keywords: Abundance, Environmental Assessment, Invertivores, Richness, Substrate.

1 Programa de Pós-Graduação em Ecologia Aplicada (PPGECO), Universidade Federal de Lavras, Departamento de Biologia, Campus Universitário, 37200-000 Lavras, MG, Brazil. alexandre.peressin@gmail.com (corresponding author).

2 Laboratório de Ecologia de Peixes, Universidade Federal de Lavras (UFLA), Departamento de Biologia, Campus Universitário, 37200-000 Lavras, MG, Brazil. rucasarim@gmail.com.

3 Pisces - consultoria e serviços ambientais, Rua Comandante Vilas Boas, 35, Jardim Floresta, 37200-000 Lavras, MG, Brazil ivogaviaoprado@gmail.com.

4 Departamento de Ciências Ambientais (DCA), Universidade Federal de São Carlos (UFSCar), Rodovia João Leme dos Santos, km 110, 18052-780 Sorocaba, SP, Brazil. mcetra@ufscar.br. 
A estrutura trófica da assembleia de peixes é um dos indicadores mais sensíveis a alterações ambientais em riachos. Considerando a relevância de entender a resposta de grupos tróficos à alteração ambiental, este estudo buscou preencher esta lacuna científica avaliando a influência da composição do substrato, variabilidade de meso-hábitats e estabilidade das margens sobre riqueza, biomassa e número de indivíduos de peixes carnívoros, invertívoros, onívoros e herbívoros-detritívoros. Amostramos com pesca elétrica 13 trechos de riachos de Mata Atlântica com estado de conservação variável, localizados na parte superior da bacia do alto rio Paranapanema. Os pontos amostrais foram ranqueados pelo índice de hábitat fisico. Riachos mais presevados apresentaram mais galhos, troncos, matacões e blocos no substrato, maior variabilidade de meso-hábitats e maior quantidade de raízes, troncos e rochas nas margens. As correlações canônicas explicaram mais de $90 \%$ da variabilidade dos dados. A riqueza e o número de indivíduos de invertívoros aumentaram em riachos mais preservados, enquanto que a riqueza de carnívoros e o número de indivíduos onívoros diminuíram. Estes resultados demonstram que a estrutura trófica varia em resposta ao nível de preservação, e que a riqueza de invertívoros é o melhor indicador de respostas da estrutura trófica às alterações do hábitat em riachos.

Palavras-chave: Abundância, Avaliação Ambiental, Invertívoros, Riqueza, Substrato.

\section{INTRODUCTION}

The study of trophic structure is an important tool for evaluating fish assemblage structure (Angermeier, Karr, 1983; Nimet et al., 2015). Since environmental filters act by selecting assemblage species according to their traits, the effects of physical habitat characteristics on trophic structure may be a more accurate predictor than taxonomic composition (Teresa et al., 2016). Additionally, investigating different aspects of trophic structure can help detect patterns and predict assemblage responses to different environmental conditions, which are fundamental aspects to biodiversity conservation (Cruz et al., 2013).

Habitat characteristics promote alterations in trophic structure (Cunico et al., 2011) and in-stream habitat homogenization, often due to anthropogenic causes, is expected to promote less diverse trophic structures (Zeni, Casatti, 2014). Several habitat elements have been shown to influence fish assemblages in streams, including substrate composition and flow heterogeneity (Hugueny et al., 2010; Carvalho, TejerinaGarro, 2015). Channel morphology variables such as substrate, depth, and velocity alter trophic structure as large carnivores tend to predominate in large pools or streams (Schlosser, 1982). According to Lorion, Kennedy (2009), the impacts caused by the conversion of natural forest to pastures could alter trophic structure by increasing the density of herbivorous-detritivores fish. Additionally, Cross et al. (2013) showed that streams subjected to siltation, a form of environmental simplification in which there is 
homogenization of the substrate composition, can consequently decrease the diversity of trophic groups. Omnivorous fish tend to thrive after habitat alteration (Karr, 1981), especially in cases where larger substrate particles are replaced by smaller particles (Berkman, Rabeni, 1987). Furthermore, substrate composition can alter food availability for fish, since elements such as branches, leaves, and rocks create microhabitats not only for algae and fungi (Gordon, 1993) but for aquatic insects as well (Reid et al., 2010; Luek, Rasmussen, 2017).

Angermeier, Karr (1983) also suggest that large scale alterations in stream structure may have serious impacts on biodiversity due to the effects of shading, siltation, and changes in available food types. However, identifying the effects of environmental change on the ichthyofauna may depend on the assemblage structure descriptor selected (Casatti et al., 2009a; Krause et al., 2013; Nimet et al., 2015; Feld et al., 2016; Vilmi et al., 2016).

In order to use trophic structure as a viable alternative to taxonomic approaches, the relationships between trophic structure and habitat characteristics must be well understood (Vitule et al., 2017). Therefore, we aimed to answer the question: Does substrate composition, meso-habitat variability, and bank stability correlate with richness, biomass, and number of individuals of each trophic group? We expected to detect variation in trophic group responses to habitat characteristics, especially for invertivores and herbivorous-detritivores in response to substrate composition due to the dependency of most species in these groups on substrates as foraging sites. In addition, when considering possible replacements of species by others from different trophic groups in response to environmental changes, we expected to detect a stronger response in trophic group richness than in number of individuals and biomass.

\section{MATERIAL AND METHODS}

Sampling sites. Sampling was carried out once at each of the 13 stream reaches (P1 P13) between August and December in 2010 and 2011. The sampling sites were located in the southwest region of São Paulo state, Brazil, in streams located on the Upper Paranapanema River (Fig. 1). All sampled streams were of $3^{\text {rd }}$ or $4^{\text {th }}$ order (Strahler, 1957), and were selected due to accessibility and dimensions that allowed the use of electrofishing methods. The streams were located closest to the cities of Pilar do Sul and São Miguel Arcanjo in areas surrounded by natural vegetation, Eucalyptus spp. plantations, and/or pastures. The natural vegetation covers $15 \%$ of the total area of the upper Paranapanema river basin. The vegetation was primarily composed of fragments of Atlantic rainforest, especially from phytophysiognomys tropical semi-deciduous forest and floodplain forests. However, there were also some Brazilian savannah fragments, corresponding to $0.3 \%$ of the area (Secretaria do Meio Ambiente, 2005). The region presents a humid tropical climate (Type Aw according to Köppen classification) with annual precipitation of 1,200 mm. Geologically, two structural units predominate: the Atlantic Orogenic Belt and the Paraná Sedimentary basin. The altitude varies from 600 to $800 \mathrm{~m}$ and the region has mainly low hills with slopes between 20 to $30 \%$ (CBHALPA, 2016).

Sampling. Based on previous analyses of sampled sites located within the same basin 


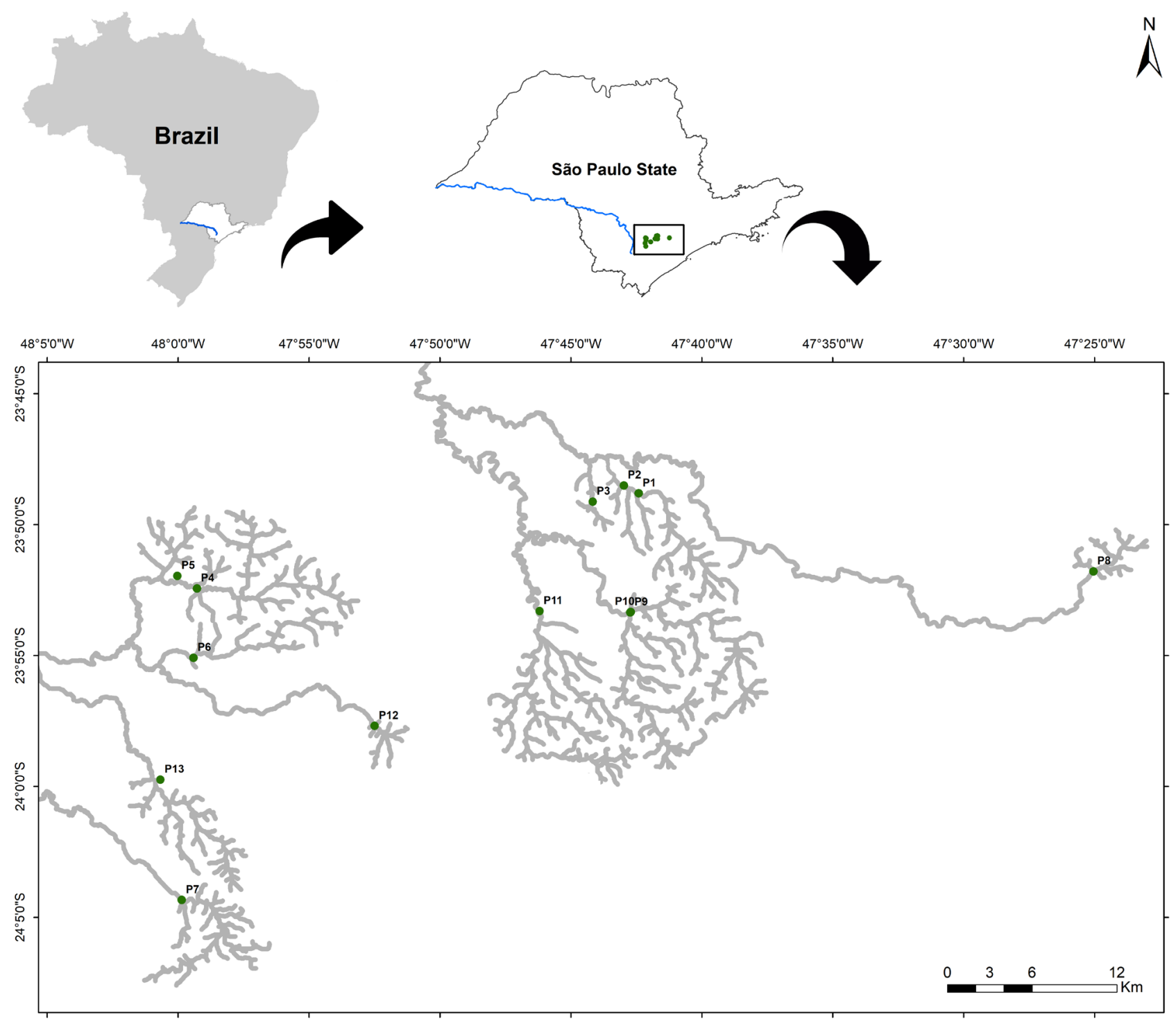

FIGURE 1 I Sampling sites located in the Paranapanema river basin, São Paulo state, Brazil. The Paranapanema river is highlighted in blue.

(see Peressin, Cetra, 2014 and Peressin et al., 2018 for more details), we considered the following habitat characteristics: substrate composition (SC), meso-habitat variability $(\mathrm{MH})$, and bank stability (BS). We established three equidistant transverse transects across each stream and recorded depth, velocity, and substrate composition in one-meter intervals along each transect. In these same transects, we recorded the composition of both sides of the river. Classification of the SC, $\mathrm{MH}$, and $\mathrm{BS}$ parameters was based on substrate elements (silt, twigs, rocks, etc.), velocity and depth combinations, and bank composition following the protocols adapted from Barbour et al. (1999) (Tab. 1). High SC scores indicate high availability of larger substrate particles such as twigs, trunks, and large substrate particles such as rocks and boulders. High MH scores indicate a great meso-habitats diversity such as alternations between shallow and deep reaches and also between high and low velocities. Elevated BS scores denote an increase of elements such as roots, trunks, and rocks in the river margins. Overall, high scores 
for these habitat parameters indicated more pristine streams while low scores indicated streams that were more affected by anthropogenic impacts. Fish sampling took place between 8 am and $5 \mathrm{pm}$, using an electrofishing apparatus. We sampled fish along a 70 $m$ reach of each stream with a single electrofishing pass from downstream to upstream, without the use of block nets. This distance is considered sufficient to emcompass the diversity of meso and micro-habitats of tropical streams (Mazzoni et al., 2000). In a laboratory, fishes were identified to the lowest possible taxonomic level. Representative ichthyofauna specimens were deposited at the fish collection of Ichthyology Laboratory of the Department of Zoology and Botany of Universidade Estadual Paulista in São José do Rio Preto, Brazil (DZSJRP) under the catalog numbers: DZSJRP 13642-43, 1364546, 13648, 13650, 13652-53, 13655-57, 13663-67, 13673-74, 13676-77, 13681-83, 13685-88, 13690-95, 13699, and 13701.

Trophic groups. The trophic group of each fish species was assigned based on a review of available literature and diet analysis. We considered the following trophic groups: carnivores - species that consume mainly invertebrates and fish; invertivores - species that consume insects and other invertebrates such as molluscs, crustaceans, and annelids; omnivores - species that consume items of plant and animal origin, and may also include detritus; and herbivorous-detritivores - species that consume mainly detritus (particulate organic matter at different stages of decomposition) and algae, including periphyton.

TABLE 1 I Criteria selected to determine the habitat score based on the substrate composition, meso-habitat variability, and bank stability habitat characteristics (Adapted from Barbour et al., 1999).

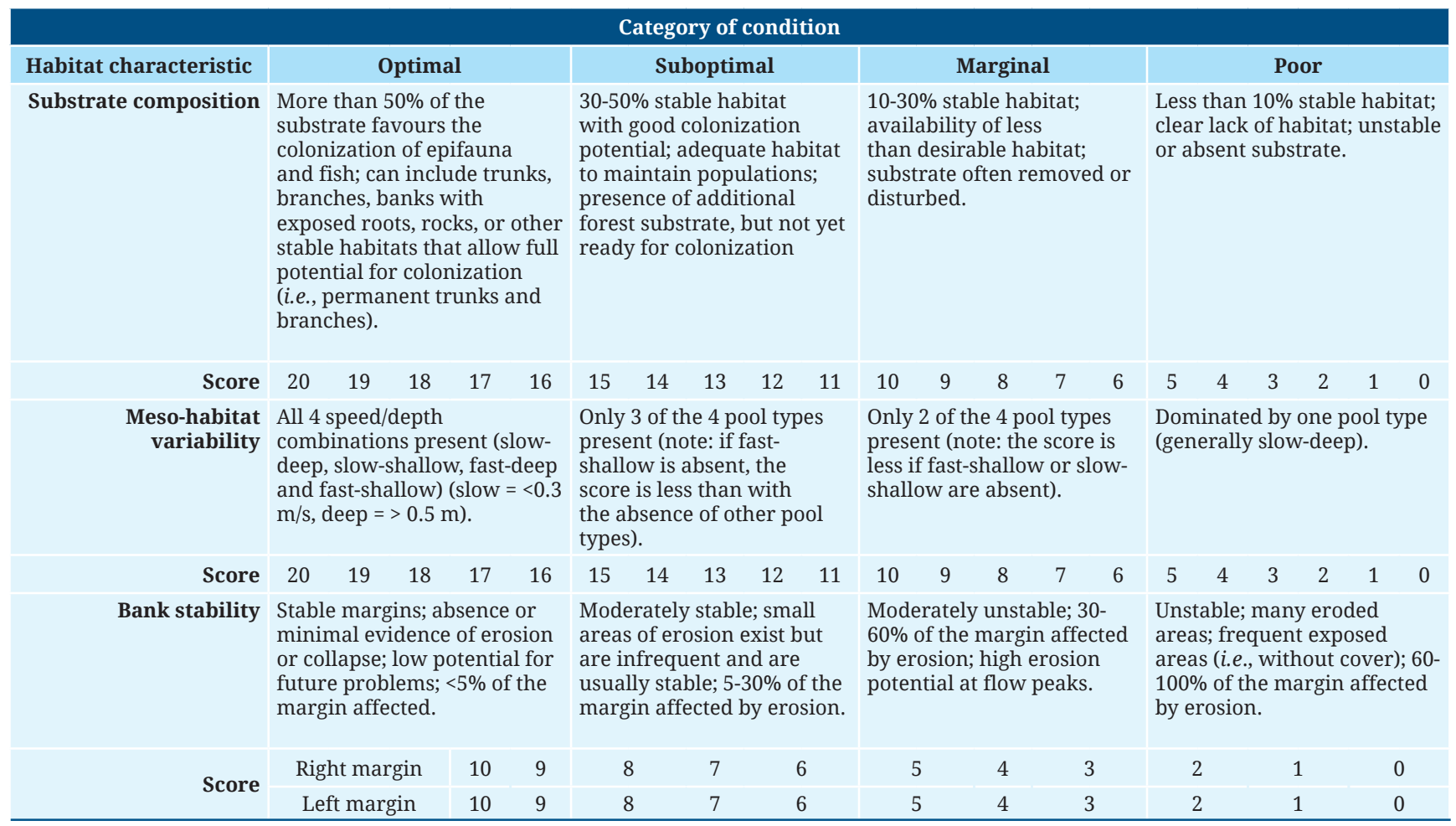


We carried out stomach content analysis for 12 individuals of Neoplecostomus selenae, an endangered species (São Paulo, 2018) for which there was no diet data in the literature. We identified stomach contents to the lowest taxonomic level possible and then classified each item into the following alimentary categories: vegetal material, algae, detritus, insects, and other invertebrates. For each item per stomach sample, we assigned values according to the method of Degree of Food Preference (DFP) (Braga, 1999). Only stomachs with full contents were considered. To calculate the DFP, we assigned values of importance for each item recorded in a sample. If only one item type was present in the stomach, it was assigned a value of 4 . For samples with more than one item type, the most abundant item was allocated the value 3 , while the values 1 and 2 were assigned to the least abundant and the intermediate items, respectively. For samples with more than 3 items, multiple items were assigned the same value, following the same procedure described above.

Statistical analyses. Considering the values assigned in the stomach content analysis, a DFP value was calculated for each alimentary category using the equation: DFP = $\mathrm{S}(\mathrm{i}) / \mathrm{N}$, where $\mathrm{S}(\mathrm{i})$ is the sum of the values assigned to each item (i) in each stomach, and $\mathrm{N}$ is the total number of analyzed stomachs.

From SC, MH, and BS scores, we calculated a physical habitat index (PHI), following an adaptation from the method used in Casatti et al. (2006). Calculations of these metric scoring thresholds were based on the distribution of total values, with the lowest threshold established at the $25^{\text {th }}$ percentile and the uppest threshold at the $75^{\text {th }}$ percentile where the former would score 1 and the latter case would score 5. Intermediate conditions, i.e., between the $75^{\text {th }}$ and $25^{\text {th }}$ percentiles of the reference sites, would score 3 . From the sum of metric scoring for each habitat parameter, we define a PHI for each stream. Again, sample points at the $25^{\text {th }}$ percentile were considered less pristine, points at $75^{\text {th }}$ percentile were considered more pristine and the remaining were considered in an intermediate condition.

To evaluate the relationship between habitat parameters and trophic groups, we conducted a canonical correlation analysis (CCorA). In this analysis, we used the three habitat characteristics as predictors for proportions within the four trophic groups at each sample point (Sherry, Henson, 2005; Legendre, Legendre, 2012). We ran three CCorA analyses: one with trophic group richness (S), another with biomass (B), and another for the number of individuals $(\mathrm{N})$ in each trophic group. Because Wilks' $\lambda$ represents the variance unexplained by the model, $1-\lambda$ yields the full model effect size in an $r^{2}$ metric. Wilks' Lambda values were calculated from the eigenvalues and converted to F statistics. With the F value we tested $\mathrm{H} 0$; the canonical correlations in the current row and all that follow are zero. For emphasis, structure (rs) and communality coefficients (h2) above 0.45 are in bold, following a convention in many factor analyses (Sherry, Henson, 2005). All analyses were performed using statistical software $\mathrm{R}$ version 3.0.0. We used the CCorA, Candisc, and Vegan R packages (R Core Team, 2018). 


\section{RESULTS}

According to PHI, sampled points P2, P6, P7 and P11 were considered more pristine, while $\mathrm{P} 5, \mathrm{P} 8$ and $\mathrm{P} 10$ were less pristine; the remaining were considered at intermediate preservation level (Tab. 2). The average width and depth of the sampling points were 4.64 and $0.34 \mathrm{~m}$, respectively.

In total, 1,356 fishes were sampled, representing 31 species. Degree of food preference values for stomachs of Neoplecostomus selenae were 0.08 for vegetal material, 1.33 for algae, 2.33 for detritus and 0.58 for insects. Three species were considered carnivores, twelve invertivores, eleven omnivores, and five herbivorousdetritivores (including N. selenae) (Tab. 3). Hoplias malabaricus had the highest number of individuals and also presented the highest biomass for the carnivore trophic group. Similarly, Pimelodella avanhandavae had both the highest number of individuals and biomass for the invertivore group. For omnivores, Phalloceros reisi had the highest number of individuals, while Geophagus brasiliensis presented the highest biomass. Hypostomus ancistroides was the herbivorous-detritivore with the highest number of individuals and biomass (Tab. 3). In general, omnivores and invertivores were dominant in terms of richness and number of individuals in our streams. However, herbivorous-detritivores had the highest biomass and highest number of individuals in the P9 and P12 streams, respectively, while carnivores presented the highest biomass in P1, P5 and P13 (Fig. 2).

TABLE 2 I Habitat characteristics in each stream reach. Substrate composition = area covered by boulders, rocks, branches, trunks, and leaves. Meso-habitat variability = combination of water velocity and depth: slow and deep, fast and shallow, and slow and shallow (deep: $>0.5 \mathrm{~m}$; fast: $>0.3 \mathrm{~m} / \mathrm{s}$ ). Bank stability = percentage of banks covered by rocks, vegetation and logs. PHI = physical habitat index . Stream order determined according to Strahler (1957).

\begin{tabular}{|c|c|c|c|c|c|c|}
\hline \multirow{2}{*}{ Stream } & \multirow{2}{*}{ Order } & \multirow{2}{*}{$\begin{array}{c}\text { Substrate } \\
\text { composition }\end{array}$} & $\begin{array}{c}\text { Meso-habitat } \\
\text { variability }\end{array}$ & \multicolumn{2}{|c|}{ Bank stability } & \multirow{2}{*}{ PHI } \\
\hline P1 & 3 & 9.6 & 8.5 & 4.0 & 1.8 & 9 \\
\hline P2 & 3 & 9.8 & 20.0 & 0.5 & 1.0 & 11 \\
\hline P3 & 3 & 0.0 & 5.0 & 6.7 & 6.7 & 9 \\
\hline P4 & 4 & 8.0 & 16.7 & 0.3 & 0.7 & 9 \\
\hline P6 & 4 & 1.3 & 7.4 & 0.7 & 0.2 & 5 \\
\hline P7 & 3 & 9.1 & 17.0 & 0.7 & 0.7 & 11 \\
\hline P8 & 3 & 16.0 & 16.0 & 10.0 & 10.0 & 13 \\
\hline P10 & 3 & 4.3 & 4.1 & 2.0 & 5.0 & 5 \\
\hline P11 & 4 & 13.0 & 4.3 & 2.0 & 4.3 & 9 \\
\hline P12 & 4 & 11.5 & 4.3 & 0.8 & 0.5 & 5 \\
\hline P13 & 4 & 13.0 & 15.2 & 6.2 & 6.2 & 13 \\
\hline Minimum & 3 & 4.8 & 14.8 & 4.0 & 3.5 & 9 \\
\hline Maximum & 4 & 12.5 & 4.3 & 4.3 & 4.8 & 7 \\
\hline
\end{tabular}


TABLE 3 I Data used to assess trophic group descriptors. Car = Carnivore; Inv = Invertivore; Omn = Omnivore; H-D = Herbivorous-Detritivores. References: 1 - Motta, Uieda (2004); 2 - Oliveira, Bennemann (2005); 3 - Gealh (2007); 4 - Gomiero, Braga (2008); 5 - Casatti et al. (2009B); 6 - LobonCerviá, Bennemann (2000); 7 - Rondinelli et al. (2011); 8 - Casatti et al. (2012); 9 - Silva et al. (2012); 10 Montenegro et al. (2012); 11 - Lujan et al. (2012); 12 - Smith et al. (2013); 13 - This study.

\begin{tabular}{|c|c|c|c|c|}
\hline Taxon & $\begin{array}{c}\text { Number } \\
\text { of individuals }\end{array}$ & Biomass (g) & $\begin{array}{l}\text { Trophic } \\
\text { group }\end{array}$ & Reference \\
\hline \multicolumn{5}{|l|}{ Characiformes } \\
\hline \multicolumn{5}{|l|}{ Characidae } \\
\hline Astyanax lacustris (Lutken, 1875) & 19 & 167.9 & Omn & 8 \\
\hline Astyanax bockmanni Vari, Castro, 2007 & 95 & 157.6 & Omn & 8 \\
\hline Astyanax fasciatus (Cuvier, 1819) & 99 & 718.3 & Omn & 8 \\
\hline Astyanax paranae Eigenmann, 1914 & 23 & 123.3 & Omn & 8 \\
\hline Piabarchus stramineus (Eigenmann, 1908) & 26 & 33.2 & Inv & 8 \\
\hline Hyphessobrycon anisitsi (Eigenmann, 1907) & 55 & 40.2 & Omn & 2 \\
\hline Piabina argentea Reinhardt, 1867 & 26 & 48.2 & Inv & 5 \\
\hline \multicolumn{5}{|l|}{ Crenuchidae } \\
\hline Characidium gomesi Travassos, 1956 & 33 & 37.5 & Inv & 8 \\
\hline Characidium schubarti Travassos, 1955 & 20 & 35.0 & Inv & 1 \\
\hline Characidium zebra Eigenmann, 1909 & 23 & 29.2 & Inv & 8 \\
\hline \multicolumn{5}{|l|}{ Erythrinidae } \\
\hline Hoplias malabaricus (Bloch, 1794) & 20 & 1209.6 & Car & 8 \\
\hline \multicolumn{5}{|l|}{ Parodontidae } \\
\hline Apareiodon piracicabae (Eigenmann, 1907) & 18 & 34.9 & Omn & 3 \\
\hline Parodon nasus Kner, 1859 & 4 & 9.5 & Omn & 4 \\
\hline \multicolumn{5}{|l|}{ Gymnotiformes } \\
\hline \multicolumn{5}{|l|}{ Gymnotidae } \\
\hline Gymnotus sylvius Albert, Fernandes-Matioli, 1999 & 8 & 226.6 & Inv & 8 \\
\hline \multicolumn{5}{|l|}{ Siluriformes } \\
\hline \multicolumn{5}{|l|}{ Heptapteridae } \\
\hline Cetopsorhamdia iheringi Schubart, Gomes, 1959 & 24 & 28.1 & Inv & 8 \\
\hline Imparfinis borodini Mees, Cala, 1989 & 25 & 494.7 & Inv & 7 \\
\hline Imparfinis mirini Haseman, 1911 & 206 & 348.1 & Inv & 8 \\
\hline Phenacorhamdia tenebrosa (Schubart, 1964) & 6 & 2.6 & Inv & 8 \\
\hline Pimelodella avanhandavae Eigenmann, 1917 & 241 & 644.5 & Inv & 8 \\
\hline Rhamdia quellen (Quoy, Gaimard, 1824) & 15 & 266.4 & Car & 9 \\
\hline Trichomycterus sp. & 17 & 26.0 & Inv & 9 \\
\hline \multicolumn{5}{|l|}{ Loricariidae } \\
\hline Hisonotus sp. & 40 & 13.4 & HD & 11 \\
\hline Hypostomus ancistroides (Ihering, 1911) & 62 & 458.2 & HD & 2 \\
\hline Hypostomus nigromaculatus (Schubart, 1967) & 5 & 49.3 & HD & 11 \\
\hline $\begin{array}{r}\text { Neoplecostomus selenae Zawadzki, Pavanelli, Langeani, } \\
2008\end{array}$ & 25 & 130.7 & HD & 13 \\
\hline Neoplecostomus sp. & 7 & 11.5 & HD & 11 \\
\hline Rineloricaria pentamaculata Langeani, Araújo, 1994 & 37 & 140.2 & Omn & 9 \\
\hline \multicolumn{5}{|l|}{ Pimelodidae } \\
\hline Pimelodus maculatus La Cepède, 1803 & 2 & 105.9 & Omn & 6 \\
\hline \multicolumn{5}{|l|}{ Cyprinodontiformes } \\
\hline \multicolumn{5}{|l|}{ Poeciliidae } \\
\hline Phalloceros reisi Lucinda, 2008 & 108 & 44.9 & Omn & 12 \\
\hline \multicolumn{5}{|l|}{ Synbranchiformes } \\
\hline \multicolumn{5}{|l|}{ Synbranchidae } \\
\hline Synbranchus marmoratus Bloch, 1795 & 8 & 193.1 & Car & 10 \\
\hline \multicolumn{5}{|l|}{ Cichliformes } \\
\hline \multicolumn{5}{|l|}{ Cichlidae } \\
\hline Geophagus brasiliensis (Quoy, Gaimard, 1824) & 59 & 1050.9 & Omn & 8 \\
\hline Total & 1356 & 6879.2 & & \\
\hline
\end{tabular}




\section{Richness}

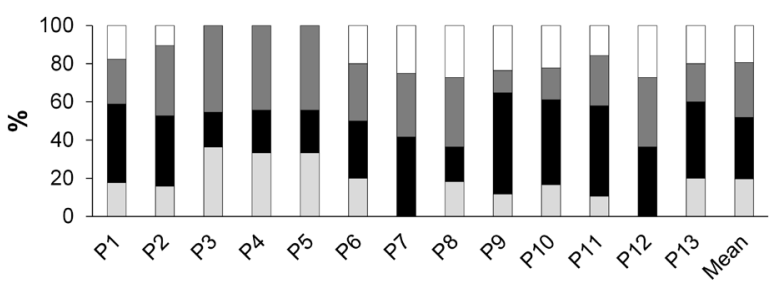

Biomass

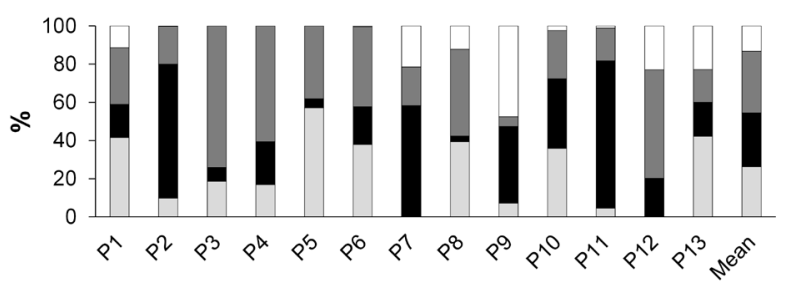

Number of individuals

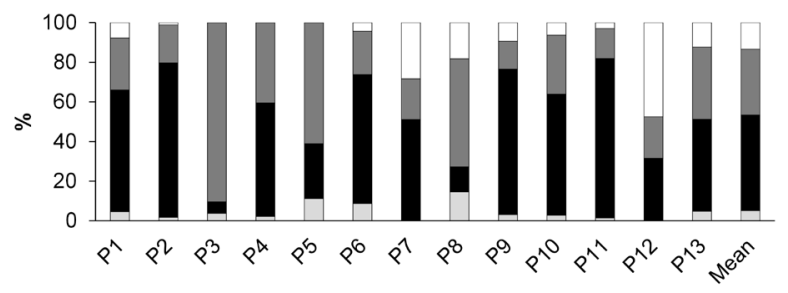

$\square$ Carnivores $\square$ Invertivores $\square$ Omnivores $\square$ Herbivorous-Detritivores

FIGURE 2 I Proportion of fish species richness, biomass, and number of individuals in each trophic group for each sampling point in the Paranapanema river basin, São Paulo state, Brazil.

The measured habitat characteristics were significantly related with trophic group richness. The CCorA analysis for richness yielded three functions (F1, F2, and F3) $\left(\mathrm{r}^{2}: \mathrm{F} 1=0.885 ; \mathrm{F} 2=0.678 ; \mathrm{F} 3=0.048\right)$ and the full model across all functions was statistically significant according to Wilks's $(\lambda=0.035)$ or $F(12,16.16)(=3.4204, p=$ $0.012)$ criteria. Thus, for the set of three canonical functions, the $r^{2}$ type effect size is 0.965, which indicates that the full model explained a substantial proportion (96.5\%) of the variance shared between the variables. The first two functions (F1 and F2) were retained because they explained most of the variability in the data. In F1, the $\mathrm{MH}$ variable was the primary contributor to the predictor synthetic variable. Considering the F1 coefficients, the relevant criterion variables were richness of omnivores (SOmn) and invertivores (SInv), which reverse signs. This indicates that an increase of mesohabitat diversity was followed by an increase in the omnivores richness and a decrease in the invertivores richness. As for F2, all habitat parameters were positively related to SInv and negatively related to carnivore richness (SCar). This suggests that streams with heterogeneous substrate (with boulders, rocks, trunks, and leaves), high mesohabitat diversity, and stable banks (with rocks, vegetation, and roots) present more invertivores species and less carnivores species (Tab. 4, Fig. 3). Since higher scores for habitat parameters indicate more pristine streams, these results suggest that physical habitat degradation due to human activities (land use change) can lead to a decrease in 
invertivores species.

Habitat parameters were not related with trophic group biomass (Wilks's $1-\lambda=0.85$; $\mathrm{p}=0.069)$ but were significantly related with trophic group number of individuals. When analysing the number of individuals, the full model across all functions was significant (Wilks's $1-\lambda=0.94 ; \mathrm{p}=0.034$ ). The $\mathrm{SC}_{-}$and $\mathrm{BS}$ variables were the main contributors to the F1 function. The number of individuals for both omnivores (NOmn) and invertivores (NInv) varied significantly with the variables. However, these two trophic groups presented a contrasting relationship, indicating that streams with high SC scores (i.e., substrate that includes boulders, rocks, wood and leaves) and high BS scores (river banks that consist of rocks, wood and roots etc.) contain less omnivores and more invertivores, in number of individuals (Tab. 4, Fig. 4).

TABLE 4 I Canonical solution for habitat characteristics predicting richness, biomass and number of individuals in each trophic group for Functions 1 and 2. Structure coefficients $\left(\mathrm{r}_{\mathrm{s}}\right)$ greater than $|.45|$ are in bold. Communality coefficients $\left(\mathrm{h}^{2}\right)$ greater than $45 \%$ are also in bold. Symbols: Coef = standardized canonical function coefficient; $r_{s}=$ structure coefficient; $r_{c}^{2}=$ squared structure coefficient. Functions 1 and 2 explained, respectively, $78.07 \%$ and $21.41 \%$ of the shared variance for richness, $57.08 \%$ and $38.31 \%$ for biomass, and $90.79 \%$ and $6.07 \%$ for number of individuals.

\begin{tabular}{|c|c|c|c|c|c|c|c|}
\hline \multirow{2}{*}{ Variable } & \multicolumn{3}{|c|}{ Function 1} & \multicolumn{3}{|c|}{ Function 2} & \multirow[b]{2}{*}{$h^{2}(\%)$} \\
\hline & Coef & $\mathrm{r}_{\mathrm{s}}$ & $\mathrm{r}_{\mathrm{s}}^{2}(\%)$ & Coef & $\mathrm{r}_{\mathrm{s}}$ & $\mathrm{r}_{\mathrm{s}}^{2}(\%)$ & \\
\hline \multicolumn{8}{|c|}{ Richness } \\
\hline Carnivores & 23.33 & 0.02 & 0.04 & -51.27 & 0.67 & 44.89 & 44.93 \\
\hline Invertivores & 23.38 & -0.49 & 24.01 & -51.38 & -0.67 & 44.89 & 68.90 \\
\hline Omnivores & 23.48 & 0.83 & 68.89 & -51.36 & 0.38 & 14.44 & 83.33 \\
\hline Herbivorous-detritivores & 23.36 & -0.35 & 12.25 & -51.31 & -0.41 & 16.81 & 29.06 \\
\hline $\mathrm{r}_{\mathrm{c}}^{2}$ & & & 88.48 & & & 67.80 & \\
\hline Substrate composition & -0.15 & -0.43 & 18.49 & -0.15 & -0.90 & 81.00 & 99.49 \\
\hline Meso-habitat variability & 0.14 & 0.67 & 44.89 & -0.06 & -0.54 & 29.16 & 74.05 \\
\hline Bank stability & 0.07 & 0.22 & 4.84 & -0.04 & -0.46 & 21.16 & 26.00 \\
\hline \multicolumn{8}{|c|}{ Biomass } \\
\hline Carnivores & -2.68 & -0.25 & 6.25 & 32.32 & 0.65 & 42.25 & 48.50 \\
\hline Invertivores & -2.67 & 0.63 & 39.69 & 32.28 & -0.51 & 26.01 & 65.70 \\
\hline Omnivores & -2.72 & -0.83 & 68.89 & 32.28 & -0.15 & 2.25 & 71.14 \\
\hline Herbivorous-detritivores & -2.67 & 0.44 & 19.36 & 32.32 & 0.22 & 4.84 & 24.20 \\
\hline $\mathrm{r}_{\mathrm{c}}^{2}$ & & & 73.34 & & & 64.86 & \\
\hline Substrate composition & 0.21 & 0.98 & 96.04 & 0.04 & -0.16 & 2.56 & 98.60 \\
\hline Meso-habitat variability & -0.03 & 0.08 & 0.64 & -0.16 & -0.88 & 77.44 & 78.08 \\
\hline Bank stability & -0.01 & 0.22 & 4.84 & -0.08 & -0.40 & 16.00 & 20.84 \\
\hline \multicolumn{8}{|c|}{ Number of individuals } \\
\hline Carnivores & 15.47 & -0.42 & 17.64 & -9.65 & 0.47 & 22.09 & 39.73 \\
\hline Invertivores & 15.50 & 0.92 & 84.64 & -9.84 & 0.04 & 0.16 & 84.80 \\
\hline Omnivores & 15.46 & -0.88 & 77.44 & -9.86 & 0.11 & 1.21 & 78.65 \\
\hline Herbivorous-detritivores & 15.47 & -0.05 & 0.25 & -9.89 & -0.41 & 16.81 & 17.06 \\
\hline $\mathrm{r}_{\mathrm{c}}^{2}$ & & & 89.05 & & & 35.23 & \\
\hline Substrate composition & 0.19 & 0.87 & 75.69 & 0.01 & -0.30 & 9.00 & 84.69 \\
\hline Meso-habitat variability & 0,04 & 0,49 & 24,01 & $-0,07$ & $-0,37$ & 13,69 & 37,70 \\
\hline Bank stability & $-0,07$ & $-0,17$ & 2,89 & $-0,16$ & $-0,91$ & 82,81 & 85,70 \\
\hline
\end{tabular}




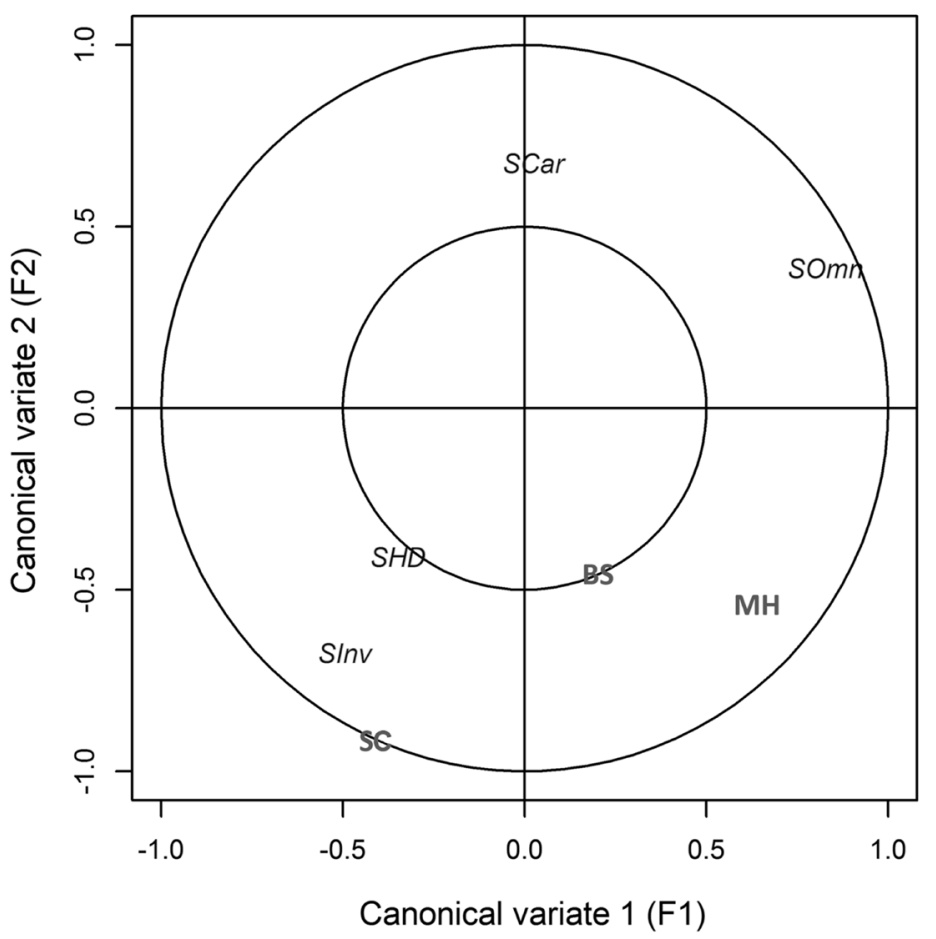

FIGURE 3 I Biplot of the first two canonical functions showing how substrate composition (SC), meso-habitat variability (MH), and bank stability (BS) correlate with richness of carnivores (SCar), invertivores (SInv), omnivores (SOmn), and herbivorous-detritivores (SHD).

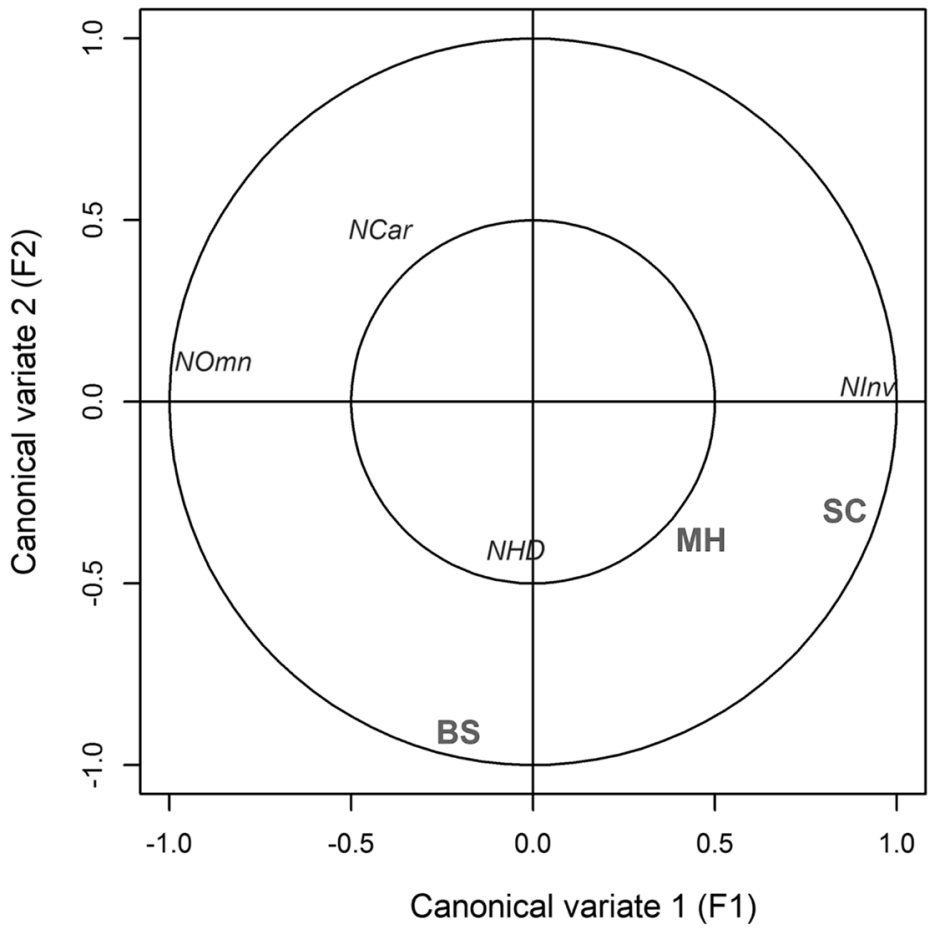

FIGURE 4 I Biplot of the first two canonical functions showing how substrate composition (SC), mesohabitat variability $(\mathrm{MH})$, and bank stability (BS) correlate with number of individuals of carnivores (NCar), invertivores (NInv), omnivores (NOmn), and herbivorous-detritivores (NHD). 


\section{DISCUSSION}

Our study results demonstrated that $\mathrm{SC}, \mathrm{MH}$, and BS influence trophic structure of fish assemblages, considering both richness and number of individuals. Invertivorous and omnivorous fish exhibit contrasting responses to habitat structure in terms of richness and number of individuals. Richness and number of individuals of invertivores increased in streams with larger substrate particles, meso-habitat variability, and bank stability, while the opposite was true of omnivorous fish. Similarly, opposite response patterns were revealed between invertivorous and carnivorous fish, but only for species richness. Although the results of the biomass model were not significant, the same pattern was observed for the three trophic groups. Herbivorous-detritivores, on the other hand, presented no significant response to any of the habitat characteristics.

In stream habitats, changes in the banks can result in changes in flow (Vietz et al., 2018) which, in turn, can alter substrate composition (Shields et al., 1994), the latter being a key aspect for changes in fish assemblages (Hortle, Lake, 1983). Higher scores for $\mathrm{SC}, \mathrm{MH}$, and $\mathrm{BS}$ were generally associated with more intact environments since lower scores indicated a predominance of smaller particles in the substrate, such as sand and silt, more homogeneous flow, and exposed margins - all characteristics typical of more degraded environments (Kemp et al., 2011; Leal et al., 2016). Consequently, our results indicate a higher number of species and number of individuals of invertivorous fish in more pristine environments.

We found that the number of invertivore individuals increased with higher SC and BS scores, and that invertivore species richness was positively correlated to all measured habitat characteristics. Despite some nektonic species such as Piabina argentea and Piabarchus stramineus (Ferreira, 2007), invertivores in our study comprised mainly species associated with fast water and substrates composed of larger diameter particles. These include the nectobenthic Characidium spp. (Sabino, Castro, 1990) and heptapterid catfishes (Siluriformes: Heptapteridae) that practice substrate speculation (Casatti et al., 2009b). Benthic invertivores have often been associated with preserved streams (Teresa, Casatti, 2012; Krause et al., 2013). Furthermore, their feeding habits are frequently correlated with morphological characteristics, leading to dependence on substrate type (Ribeiro et al., 2016). Most invertivore species in our study had large pectoral fins, flattened dorsal-ventral bodies and wide mouths (Ribeiro et al., 2016). Such species tend to be benthic, rheophilic, and are sensitive to changes in substrate composition especially siltation which, in turn, leads to changes in flow; these species are generally associated with structurally complex and pristine environments (Teresa, Casatti, 2012; Cruz et al., 2013).

In more simplified environments, generalist species tend to prevail (Bozzeti, Schulz, 2004; Casatti et al., 2015). In our study, omnivorous fish decreased in richness, responding to an increase in SC, MH, and BS. However, since we used the proportion of trophic groups to represent trophic structure, an increase in the values of richness and number of individuals for invertivores can result in an apparent reduction in the participation of omnivores in the trophic structure, even though the latter does not present an actual reduction in the number of individuals. The omnivore group was mainly represented by species that present nektonic foraging habits and are able to forage in different environments (Sabino, Castro, 1990; Gomiero, Braga, 2008). Moreover, omnivore 
species richness responded positively to $\mathrm{MH}$. This group also included species with diverse habits, such as Astyanax spp. and Geophagus brasliensis, with deep, laterallycompressed bodies and terminal mouths; the genus Phalloceros, whose representative species are commonly observed in pools and slow waters and feed on the surface of shallow waters (Casatti, 2002); and Pimelodus maculatus, species associated with deeper parts of the water column (Lobon Cerviá, Bennemann, 2000).

The richness of carnivorous species decreased in streams with higher substrate diversity, mesohabitat diversity, and bank stability, i.e., more pristine streams. In our study, carnivores were represented predominantly by H. malabaricus and Rhamdia quellen, two of the largest species collected. Both are found mainly in waters with greater depth and slower water velocity, if compared with other stream species (Daga et al., 2012; Teresa, Casatti, 2012; Peressin, Cetra, 2014). As this meso-habitat generally has smaller substrate particles than high velocity meso-habitats, these species tends to occur in restricted conditions of SC and $\mathrm{MH}$. For herbivorous-detritivores, on the other hand, a positive relationship with SC was expected, since many species from this group have specialized buccal morphology for grazing which allows the consumption of periphyton on hard substrates (Lujan et al., 2012). However, we did not detect a significant relationship between any of the trophic structure predictors of herbivorous-detritivores and the habitat characteristics measured. This may be explained by the fact that fish species in this group also consume detritus, which commonly occurs in almost all types of habitat, and it is therefore a food resource that is not restrictive (Peressin et al., 2018). Furthermore, the species with the highest number of individuals in this group was $H$. ancistroides, a species tolerant to reductions in environmental quality due to pollution (Smith et al., 1997), and it has been also considered a reliable indicator of anthropogenically altered environments (Oliveira, Bennemann, 2005).

The CCorA for richness explained greater amounts of variance in trophic groups than CCorA for biomass and number of individuals. Diversity indices generally ignore fish species identity and their roles in the community (Green, 1979). Consequently, species replacement may keep richness unchanged, preventing the detection of alterations and impacts on the fish assemblage (Scott, Helfmann, 2001). Trophic structure, on the other hand, incorporates species feeding habits, providing insights into ecological function and reflecting the role of species within an assemblage as well as their relationships with the environment. According to Teresa et al. (2016), in similar environmental conditions, different species of the same trophic group may replace each other. As a result, trophic structure would remain unchanged. On the other hand, as observed in this study, under physical environmental changes, species can be replaced by others with different feeding habits.

Invertivores species richness varied in response to all habitat parameters analysed in this study. In addition, invertivores richness and number of individuals were greater in more pristine streams, which had substrate composed by larger substrate particles, more variations between depth and shallow waters, more variations between high and low velocities, and more rocks and trunks along river banks. Furthermore, invertivore richness presented changes related to all measured habitat characteristics, and the richness canonical correlation explained a greater amount of variance in this data. Thus, we conclude that trophic structure can be a good indicator of environmental alteration, 
and, more specifically, species richness of invertivores offers the best indicator of trophic structure responses to physical environmental changes in streams, and should be considered in further studies.

\section{ACKNOWLEDGMENTS}

We thank the Fundação de Amparo à Pesquisa do Estado de São Paulo (FAPESP) for the regular assistance to the research project "Study of physical and biotic integrity of headwater streams that cross the Atlantic Forest of São Paulo" (2009/53056 -8) granted to Mauricio Cetra and the master's degree scholarship awarded to the first author (2010/13758-0). We are grateful to Dr. Francisco Langeani Neto (UNESP São of Rio Preto), for the aid in the identification of the species and Bruna Botti Cruz, Bruno Mello, Fernanda Ayumi Teshima and Rodrigo da Silva Almeida for help in the field. We are also greatful to two anonymous reviewers by suggestions to improve the manuscript. Natalie Swan translated the manuscript to English and Jessica Schulte reviewed for English clarity.

\section{REFERENCES}

- Angermeier PL, Karr JR. Fish communities along environmental gradients in a system of tropical streams. Environ Biol Fish. 1983; 9(2):117-35. https://doi.org/10.1007/BF00690857

- Barbour MT, Gerritsen J, Snyder BD, Stribling JB. Rapid bioassessment protocols for use in streams and wadeable rivers: periphyton, benthic macroinvertebrates and fish. 2nd ed. Washington DC: EPA 841-B-99-002. US Environmental Protection Agency, Office of Water. [Internet]. Washington DC; 1999. Available from: https://play. google.com/books/reader?id=biH8Dj_ r6LMC\&hl=pt\&pg=GBS.SA3-PA10

- Berkman HE, Rabeni CF. Effect of siltation on stream fish communities. Environ Biol Fish. 1987; 18(4):285-94. https://doi. org/10.1007/BF00004881

- Bozzetti M, Schulz UH. An index of biotic integrity based on fish assemblages for subtropical streams in southern Brazil. Hydrobiologia. 2004; 529:133-44. https:// doi.org/10.1007/s10750-004-5738-6
- Braga ALC, Pompeu PS, Carvalho RF, Ferreira RL. Dieta e crescimento de Synbranchus marmoratus (Bloch, 1975) (Pisces, Synbranchiformes) durante período de pré-estivação em uma lagoa marginal da bacia do São Francisco, Minas Gerais. Rev Bras Zoociências. 2008; 10(2):133-38. Available from: https:// periodicos.ufjf.br/index.php/zoociencias/ article/view/24060

- Braga FMS. O grau de preferência alimentar: um método qualitativo e quantitativo para o estudo do conteúdo estomacal de peixes. Acta Sci. 1999; 21(2):291-95. Available from: http:// periodicos.uem.br/ojs/index.php/ ActaSciBiolSci/article/view/4445/3034

- Carvalho RA, Tejerina-Garro FL. Environmental and spatial processes: what controls the functional structure of fish assemblages in tropical rivers and headwater streams? Ecol Freshw Fish. 2015; 24(2):317-28. https://doi.org/10.1111/ eff.12152

- Casatti L. Alimentação dos peixes em um riacho do Parque Estadual Morro do Diabo, Bacia do Alto Rio Paraná, sudeste do Brasil. Biota Neotrop. 2002; 2(2):1-14. https://doi. org/10.1590/S1676-06032002000200012 
- Casatti L, Langeani F, Ferreira CP. Effects of physical habitat degradation on the stream fish assemblage structure in a pasture region. Environ Manage. 2006; 38:974-82. https://doi.org/10.1007/s00267005-0212-4

- Casatti L, Ferreira CP, Langeani F. A fishbased biotic integrity index for assessment of lowland streams in southeastern Brazil. Hydrobiologia. 2009a; 623:173-89. https:// doi.org/10.1007/s10750-008-9656-x

- Casatti L, Ferreira CP, Carvalho FR. Grass-dominated stream sites exhibit low fish species diversity and dominance by guppies: an assessment of two tropical pasture river basins. Hydrobiologia. 2009b; 632:273-83. https://doi.org/10.1007/s10750009-9849-y

- Casatti L, Teresa FB, Gonçalves-Souza T, Bessa E, Manzotti AR, Gonçalves CS, Zeni JO. From forests to cattail: how does the riparian zone influence stream fish? Neotrop Ichthyol. 2012; 10(1):205-14. https://doi.org/10.1590/S167962252012000100020

- Casatti L, Teresa FB, Zeni JO, Ribeiro MD, Brejao GL, Ceneviva-Bastos M. More of the same: high functional redundancy in stream fish assemblages from tropical agroecosystems. Environ Manage. 2015; 55(6):1300-14. https://doi.org/10.1007/ s00267-015-0461-9

- Comitê da Bacia Hidrográfica do Alto Paranapanema (CBH - ALPA). Plano da Bacia Hidrográfica do Alto Paranapanema (UGRHI 14) 2016-2027. TCA Soluções e Planejamento Ambiental e Instituto de Pesquisas Tecnológicas do Estado de São Paulo - IPT [Internet]; São Paulo; 2016. Available from: http://www.sigrh.sp.gov.br/public/ uploads/documents//CBH-ALPA/12024/ relatorioalparevisaodezembrov5.pdf

- Cross WF, Baxter CV, Rosi-Marshall EJ, Hall RO, Kennedy TA, Donner KC, Kelly HAW, Seegert SEZ, Behn KE, Yard MD. Food-web dynamics in a large river discontinuum. Ecol Monogr. 2013; 83(3):311-37. https://doi.org/10.1890/121727.1

- Cruz BB, Teshima FA, Cetra M. Trophic organization and fish assemblage structure as disturbance indicators in headwater streams of lower Sorocaba River basin, São Paulo, Brazil. Neotrop Ichthyol. 2013; 11(1):171-78. https://doi.org/10.1590/S167962252013000100020
- Cunico AM, Allan JD, Agostinho AA. Functional convergence of fish assemblages in urban streams of Brazil and the United States. Ecol Indic. 2011; 11(5):1354-59. https://doi.org/10.1016/j. ecolind.2011.02.009

- Daga VS, Gubiani EA, Cunico AM, Baumgartner G. Effects of abiotic variables on the distribution of fish assemblages in streams wit $h$ different anthropogenic activities in southern Brazil. Neotrop Ichthyol. 2012; 10(3):64352. https://doi.org/10.1590/S167962252012000300018

- Feld CK, Birk S, Eme D, Gerisch M, Hering D, Kernan M et al. Disentangling the effects of land use and geo-climatic factors ondiversity in European freshwater ecosystems. Ecol Indic. 2016; 60:71-83. https://doi.org/10.1016/j. ecolind.2015.06.024

- Ferreira KM. Biology and ecomorphology of stream fishes from the rio Mogi-Guaçu basin, Southeastern Brazil. Neotrop Ichthyol. 2007; 5(3):311-26. https://doi. org/10.1590/S1679-62252007000300012

- Gealh AM. Ictiofauna dos rios Fortaleza, Iapó, alto e médio Tibagi. In: Melo MS, Moro RS, Guimarães GB, editors. Patrimônio natural dos Campos Gerais do Paraná. Ponta Grossa: Editora UEPG; 2007. p.151-62. Available from: http://ri.uepg.br:8080/riuepg/ bitstream/handle/123456789/460/ CAP\%c3\%8dTULO16 IctiofaunaRiosFortaleza.pdf?sequence $=1$

- Gomiero LM, Braga FMS. Feeding habits of the ichthyofauna in a protected area in the state of São Paulo, southeastern Brazil. Biota Neotrop. 2008; 8(1):41-47. https://doi. org/10.1590/S1676-06032008000100004

- Gordon ND. Stream hidrology: an introduction. Chichester: John Willey \& Sons. 1993.

- Green RH. Sampling design and statistical methods for environmental biologists. New York: John Wiley \& Sons. 1979.

- Hortle KG, Lake PS. Fish of channelized and unchannelized sections of the Bunyip River, Victoria. Mar Freshw Res. 1983; 34(3):441-50. https://doi.org/10.1071/ MF9830441 
- Hugueny B, Oberdorff T, Tedescco TA. Community Ecology of River Fishes: A Large-Scale Perspective. In: Jackson DA, Gido KB, editors. Community ecology of stream fishes: concepts, approaches, and techniques. Bethesda, Maryland: American Fisheries Society, Symposium 73; 2010. p.1-34. Available from: http://tedesco1.free. fr/Hugueny\%20et\%20al\%202010.pdf

- Karr JR. Assessment of biotic integrity using fish communities. Fisheries. 1981; 6:21-27. https://doi.org/10.1577/15488446(1981)006<0021:AOBIUF>2.0.CO;2

- Kemp P, Sear D, Collins A, Naden P, Jones I. The impacts of fine sediment on riverine fish. Hydrol Process. 2011; 25(11):1800-21. https://doi.org/10.1002/hyp.7940

- Krause JR, Bertrand KN, Kafle A, Troelstrup Jr. NH. A fish index of biotic integrity for South Dakota's Northern Glaciated Plains Ecoregion. Ecol Indic. 2013; 34:313-22. https://doi.org/10.1016/j. ecolind.2013.05.011

- Leal CG, Pompeu PS, Gardner TA, Leitão RP, Hughes RM, Kaufmann PR et al. Multi-scale assessment of human-induced changes to Amazonian instream habitats. Landsc Ecol. 2016; 31:1725-45. https://doi. org/10.1007/s10980-016-0358-X

- Legendre P, Legendre L. Numerical Ecology, 3rd ed. Amsterdam: Elsevier; 2012.

- Lobón-Cerviá J, Bennemann ST. Temporal trophic shifts and feeding diversity in two sympatric, neotropical omnivores fishes: Astyanax bimaculatus and Pimelodus maculatus in Rio Tibagi (Paraná, Southern Brazil). Arch Hydrobiol. 2000; 149(2):285306. https://doi.org/10.1127/archivhydrobiol/149/2000/285

- Lorion CM, Kennedy BP. Riparian forest buffers mitigate the effects of deforestation on fish assemblages in tropical headwater streams. Ecol Appl. 2009; 19(2):468-79. https://doi.org/10.1890/08-0050.1

- Luek A, Rasmussen JB. Chemical, physical, and biological factors shape littoral invertebrate community structure in coal-mining End-Pit Lakes. Environ Manage. 2017; 59(4):652-64. https://doi. org/10.1007/s00267-017-0819-2

- Lujan NK, Winemiller KO, Armbruster JW. Trophic diversity in the evolution and community assembly of loricariid catfishes. Evol Biol. 2012; 12(124). https:// doi.org/10.1186/1471-2148-12-124
- Mazzoni R, Fenerich-Verani N, Caramaschi EP. Electrofishing as a sampling technique for coastal stream fish populations and communities in the southeast of Brazil. Braz J Biol. 2000; 60(2):205-16. https://doi.org/10.1590/S003471082000000200003

- Motta RL, Uieda VS. Dieta de duas espécies de peixes do Ribeirão do Atalho, Itatinga, SP. Rev Bras Zoo. 2004; 6(2):191205. Available from: https://periodicos. ufjf.br/index.php/zoociencias/article/ view/24193

- Nimet J, Delariva RL, Wolff LL, Silva JC. Trophic structure of fish fauna along the longitudinal gradient of a first-order rural stream. Acta Limnol Bras. 2015; 27(4):38193. http://doi.org/10.1590/S2179-975X2915

- Oliveira DC, Bennemann ST. Ictiofauna, recursos alimentares e relações com as interferências antrópicas em um riacho urbano no sul do Brasil. Biota Neotrop. 2005; 5(1):96-107. https://doi.org/10.1590/ S1676-06032005000100011

- Peressin A, Cetra M. Responses of the ichthyofauna to urbanization in two urban areas in Southeast Brazil. Urban Ecosyst. 2014; 17(3):675-90. https://doi.org/10.1007/ s11252-014-0352-5

- Peressin A, Silva Gonçalves C, Cetra M. Ichthyofauna diet changes in response to urbanization: the case of upper Paranapanema River basin (Brazil). Urban Ecosyst. 2018; 21(4):795-803. https://doi. org/10.1007/s11252-018-0755-9

- R Development Core Team. R: A aanguage and environment for statistical computing [Computer software manual - Internet]. Vienna: R Foundation for Statistical Computing;. 2013. Available from: http://www.R-project.org/(accessed August 7th 2013).

- Reid HE, Brierley GJ, Boothroyd IKG. Influence of bed heterogeneity and habitat type on macroinvertebrate uptake in periurban streams. Int J Sediment Res. 2010; 25(3):203-20. https://doi.org/10.1016/S10016279(10)60039-X

- Ribeiro MD, Teresa FB, Casatti L. Use of functional traits to assess changes in stream fish assemblages across a habitat gradient. Neotrop Ichthyol. 2016; 14(1):e140185. Available from: http:// dx.doi.org/10.1590/1982-0224-20140185 
- Rondineli GR, Gomiero LM, Carmassi AL, Braga FMS. Diet of fishes in Passa Cinco stream, Corumbataí River subbasin, São Paulo state, Brazil. Braz J Biol. 2011; 71(1):157-67. https://doi.org/10.1590/S1519 69842011000100023

- Sabino J, Castro RMC. Alimentação, período de atividade e distribuição espacial dos peixes de um riacho da floresta Atlântica (sudeste do Brasil). Braz J Biol. 1990; 50(1):23-36.

- São Paulo, Governo do Estado. Decreto $\mathrm{N}^{\circ}$ 63.853; 2018. Available from: https:// www.al.sp.gov.br/repositorio/legislacao/ decreto/2018/decreto-63853-27.11.2018. html

- Schlosser IJ. Trophic structure, reproductive success. and growth rate of fishes in a natural and modified headwater stream. Can J Fish Aquat Sci. 1982; 39(7):968-78. https://doi.org/10.1139/ f82-132

- Scott MC, Helfman GS. Native invasions, homogenization, and the mismeasure of integrity of fish assemblages. Fisheries. 2001; 26(11):6-15. https://doi. org/10.1577/1548-8446(2001)026<0006:NIH ATM>2.0.CO;2

- Secretaria de Meio Ambiente. Inventário Florestal da Vegetação Natural do Estado de São Paulo. Governo do Estado de São Paulo; 2008. Available from: https://www. infraestruturameioambiente.sp.gov.br/ institutoflorestal/2005/03/inventarioflorestal-da-vegetacao-natural-do-estadode-sao-paulo/

- Sherry A, Henson RK. Conducting and interpreting canonical correlation analysis in personality research: a userfriendly primer. J Pers Assess. 2005; 84:37-48. https://doi.org/10.1207/ s15327752jpa8401_09

- Shields Jr FD, Knight SS, Cooper CM. Effects of channel incision on base flow stream habitats and fishes. Environ Manage. 1994; 18(1):43-57. https://doi. org/10.1007/BF02393749

- Silva JC, Delariva RL, Bonato KO. Foodresource partitioning among fish species from a first-order stream in northwestern Paraná, Brazil. Neotrop Ichthyol. 2012; 10(2):389-99. https://doi.org/10.1590/S167962252012005000008
- Smith WS, Barrella W, Cetra M. Comunidade de peixes como indicadora de poluição. Rev Bras Ecol 1997; 1:67-71.

- Smith WS, Biagioni R, Halcsik L. Fish fauna of Floresta Nacional de Ipanema, São Paulo State, Brazil. Biota Neotrop. 2013; 13(2):175-81. https://doi.org/10.1590/ S1676-06032013000200016

- Strahler AN. Quantitative analisys of watershed geomorphology. Trans Am Geophys Union. 1957; 38(6):913-20. https:// doi.org/10.1029/TR038i006p00913

- Teresa FB, Souza LS, Silva DMA, Barbosa HO, Lima JD, Nabout JC. Environmental constraints structuring fish assemblages in riffles: evidences from a tropical stream. Neotrop Ichthyol. 2016; 14(3):e150185. http://dx.doi.org/10.1590/1982-022420150185

- Teresa FB, Casatti L. Influence of forest cover and mesohabitat types on functional and taxonomic diversity of fish communities in Neotropical lowland streams. Ecol Freshw Fish. 2012; 21(3):433-42. https://doi.org/10.1111/j.16000633.2012.00562.x

- Vietz GJ, Lintern A, Webb JA, Straccione D. River bank erosion and the influence of environmental flow management. Environ Manage. 2018; 61(3):454-68. https://doi. org/10.1007/s00267-017-0857-9

- Vilmi A, Karjalainen SM, Nokela T, Tolonen K, Heino J. Unravelling the drivers of aquatic communities using disparateorganismal groups and different taxonomic levels. Ecol Indic. 2016; 60:108-18. https://doi.org/10.1016/j. ecolind.2015.06.023

- Vitule JRS, Agostinho AA, AzevedoSantos VM, Daga VS, Darwall WRT, Fitzgerald DB et al. We need better understanding about functional diversity and vulnerability of tropical freshwater fishes. Biodivers Conserv. 2017; 26:757-62. https://doi.org/10.1007/s10531-016-1258-8

- Zeni JO, Casatti L. The influence of habitat homogenization on the trophic structure of fish fauna in tropical streams. Hydrobiologia. 2014; 726:259-70. https:// doi.org/10.1007/s10750-013-1772-6 


\section{Neotropical Ichthyology}

\section{open access $_{\text {a }}$}

\section{(c) (1)}

This is an open access article under the terms of the
Creative Commons Attribution License, which permits use, distribution and reproduction in any medium provided the original work is properly cited.

Distributed under

Creative Commons CC-BY 4.0

๑ 2020 The Authors.

Diversity and Distributions Published by SBI

3 Official Journal of the

SBI

\section{AUTHOR'S CONTRIBUTION (1)}

Alexandre Peressin: Conceptualization, Data curation, Formal analysis, Investigation, Methodology,

Writing-original draft, Writing-review \& editing.

Ruanny Casarim: Data curation, Investigation, Writing-original draft, Writing-review \& editing.

Ivo Gavião Prado: Investigation, Writing-original draft, Writing-review \& editing.

Maurício Cetra: Data curation, Formal analysis, Funding acquisition, Investigation, Methodology, Project administration, Resources, Software, Supervision, Writing-original draft, Writing-review \& editing.

\section{ETHICAL STATEMENT}

The fishes was collected under the License $\mathrm{n}^{\circ}$ 13352-1 SISBIO/IBAMA/MMA.

\section{COMPETING INTERESTS}

The authors declare no competing interests.

\section{HOW TO CITE THIS ARTICLE}

- Peressin A, Casarim R, Prado IG, Cetra M. Physical habitat as predictor of fish trophic structure in Brazilian Atlantic rainforest streams. Neotrop Ichthyol. 2020; 18(2):e190076. https://doi.org/10.1590/1982-0224-2019-0076 